\title{
Conversion to Islam among the Armenian elite
}

Timothy W. Greenwood

\begin{tabular}{|l|l|}
\hline Date of deposit & 18012021 \\
\hline Document version & Author's accepted manuscript \\
\hline Access rights & $\begin{array}{l}\text { Copyright C } 2021 \text { by the Regents of the University of California. } \\
\text { All rights reserved. This work has been made available online in } \\
\text { accordance with publisher policies or with permission. Permission } \\
\text { for further reuse of this content should be sought from the } \\
\text { publisher or the rights holder. This is the author created accepted } \\
\text { manuscript following peer review and may differ slightly from the } \\
\text { final published version. }\end{array}$ \\
\hline $\begin{array}{l}\text { Citation for } \\
\text { published version }\end{array}$ & $\begin{array}{l}\text { Greenwood, TW 2020, Conversion to Islam among the Armenian } \\
\text { elite. in NH, C Sahner, U Simonsohn \& L Yarbrough (eds), } \\
\text { Conversion to Islam in the Premodern Age: A Sourcebook. } \\
\text { University of California Press, Oakland, pp. 114-118. }\end{array}$ \\
\hline $\begin{array}{l}\text { Link to published } \\
\text { version }\end{array}$ & $\begin{array}{l}\text { https://www.ucpress.edu/book/9780520296732/conversion-to- } \\
\text { islam-in-the-premodern-age }\end{array}$ \\
\hline
\end{tabular}

Full metadata for this item is available in St Andrews Research

Repository at: https://research-repository.st-andrews.ac.uk/

\begin{tabular}{l|l|l|} 
University of & FOUNDED \\
St Andrews & 1413
\end{tabular}


Frontmatter:

- "Reflections on Conversion to Islam among the Armenian Elite"

- T'ovma Artsruni (Thomas Arcruni) (d. ca. $904 \mathrm{CE}$ )

- Patmut'iwn tann Artsruneats ("History of the House of Artsrunik")

- History

- T'ovma Artsruni, Patmut'iwn tann Artsruneats', ed. Gēorg Tēr-Vardanean, Matenagirk' Hayots' $10^{\text {th }}$ Century vol. 11 (Antilias: Armenian Catholicosate of Cilicia Press, 2010), pp. 178, 180-2, 186 and 227-8; Robert W. Thomson, trans. Thomas Artsruni. History of the House of Artsrunik' (Detroit: Wayne State University Press 1985), pp. 219, 221-3, 228 and 279-81

Introduction:

T'ovma is an elusive figure, unattested outside his History, and a reluctant presence within it, referring to himself only once. He was a cleric with close connections to several members of the Armenian princely family of Artsruni, who controlled lands to the east and south of lake Van. He reveals that he was asked to write a history of this princely family by one of its leading figures, Grigor Derenik. He continued it under the patronage of Grigor's second son, Gagik. The History breaks off in mid-sentence, with the Artsruni lands under threat of invasion in the year 904.

The extracts below derive from an extensive narrative reporting the campaigns of the Turkish warlord and general Bughā al-Kabīr across the lands of the Caucasus between 851 and $855 \mathrm{CE}$, undertaken at the command of the 'Abbasid caliph al-Mutawakkil. Ashot Artsruni, the father and grandfather respectively of T'ovma's patrons, was one of the leading princes who was led away into captivity to Samarra, then the 'Abbasid capital, with several members of his family, including his son Grigor Derenik. It is therefore striking that T'ovma does not gloss over Ashot's conversion but acknowledges it, together with members of other princely families, notably Bagarat Bagratuni.

Two features of the passage merit particular comment. Firstly, T'ovma's description of the tribunal is modelled closely upon passages from Etishē's earlier account of Armenian rebellion, persecution and apostasy in the middle of the fifth century, when several princes reportedly feigned submission to Zoroastrianism at the court of the Persian king. The portrait of al-Mutawakkil is based on the Sasanian king Yazdgerd II and Bughā on his vizier Mihrnerseh. T'ovma's account of forced conversion is therefore a literary reconstruction, based on older Armenian tradition. Unlike that earlier text, however, T'ovma agonizes about the consequences of their actions, indicating that some form of conversion had taken place and that it was a real issue at the time of writing.

The central question is whether conversion under duress should be treated differently? He reflects on the example of the heretical Elkesites of the early Christian period and their conviction that one could apostatize with impunity during a time of persecution. This illustration, and the response of the Roman priest Novatian to it, derive from Eusebius' Ecclesiastical History, although T'ovma maintains that Novatian changed his mind on readmitting lapsed believers, leaving the teaching unclear. His uncertainty is also a striking feature of the final extract, in which he meditates on Ashot's eternal fate in the light of his temporary denial and subsequent conduct. 
[178] All the recollections in this narrative are intense, sad and filled with bitterness at the concession of our great nobles and princes. This account is filled with tears and I am incapable of describing the circumstances of their ruinous error in straying from the orthodox and pure apostolic confession of faith in the Father and Son and Holy Spirit of the catholic church. And I do not want to apply myself to describe and set down in writing the destruction of our princely lords and whatever misfortune they brought upon their souls rather than their bodies, yet unwillingly I am compelled to write down and organize, briefly and in short, a summary, assembling in a few words a history of what transpired, because it is impossible to cover up in silence, to hide or not disclose the unfathomable and terrible troubles and misfortunes which came upon us...

[T'ovma then explains that while Ashot Artsruni and his family were in prison in Samarra, the caliph arrived in the city and summoned them before a public tribunal. They began to converse, and the caliph accused them of violent resistance and failing to pay their taxes. T'ovma continues]:

[180] "But since now I see that you are indeed of fine appearance and handsome, with your noble faces, seemly and becoming, that you are indeed the sons of kings of that country and worthy of pity, that you are indeed men of valour and it is clear from your presence that you are powerful because you have done so much harm to me. Yet you have presented yourself before me in the tribunal with untroubled and joyful faces, like innocent men who do good deeds, eager to oblige us in every way, with complete sincerity. So I will spare you and will not put an end to your lives, as your wicked deeds and the harm which you have caused me deserve. Without experiencing torments or violent tortures, accept us and our legislator Mahumat (i.e., Muhammad)', receive this faith and divinely-given religion, far from falsehood, filled with everything which is the opposite of falsehood; reject completely that useless and false worship of yours in relation to Christ to whom you, in your stubbornness, have lashed yourselves. Then we shall ignore your damaging acts against us, your lives will be spared and you will live and rule over your country and your houses, you and your sons...

[ $T$ 'ovma then explains how the bishop of Artsrunik' rejected the offer, maintaining that the unsupported testimony of the prophet Muhammad cannot withstand comparison to the one hundred and eleven witnesses to the divinity of Christ. The caliph responded by repeating his offer to the Artsruni princes]

[181] But they, although had not wanted to turn in the slightest from worshipping the Son of God, since the faith of the holy apostles had settled in their hearts, yet because it did not have roots, it withered before the heat of the devil. For at his bellowing, sparks fell and smoke of the fiery furnace came out through his nostrils, as is written in the Book of Job [Job 41:21]. And on account of their weakness of spirit and unstable and wavering minds, they loved the glory of man [182] more than the glory of God, since "This people," he says, "worship me with lips but their hearts were removed and separated from me." And being set apart from the love of God, fear of death apprehended them, especially as they did not want to leave the vain life of this transitory world, they said, "We accept the royal commands," having resolved that outwardly they would satisfy the intentions of the king but inwardly they would hold fast to their confession in Christ. But it is impossible for one person to hold both 
positions, and noone can serve two masters, as the Savior said, which I shall be required to illustrate in its own place.

Then straightaway they were circumcised as Muslims (mslimanak), following after Bagarat Bagratuni who was seized by another commander in the city of Khlat', and he was prince of Taron; he was brought to Samarra and became an apostate and he opened the broad and wide road, the path of destruction which leads to unfathomable destruction, as Jeroboam, son of Nabat, who sinned and caused Israel to $\sin .$.

[ $T^{\prime}$ ovma then comments on the willing conversion of Vasak Artsruni before describing in some detail the steadfast resistance of Yovhannēs bishop of Artsrunik', Grigor the priest and lord Grigor Artsruni. He then reflects on how Bagarat Bagratuni later defended his actions]

[186] In relation to his apostasy, Bagarat said that apostasy under threat of affliction causes no harm if one keeps secretly in one's heart the confession of faith... Let us turn to the Elkesites, those who at the time of persecution fell into the error of idolatry. And this man had the notion that if anyone should turn to the worship of idols under threat of affliction, it counts for nothing if his heart holds genuinely to the faith of Christ. At this time, Novatian, a priest in Rome, despatched people to refute the Elkesites, and at the ending of the persecution, he did not receive those who repented of sacrificing to idols. And this man prevented many from idolatry, although he caused those who had turned back in repentance to wander in despair and he ruined the whole world by being a stickler for unimportant things, although later on he did admit those who repented...

[T'ovma then reports the eventual return of Ashot Artsruni from Samarra and his struggle to re-establish himself in his former domains]

[227] Now when Ašot had reached the age of 19 years, he then exercised princely power for a further 16 years, down to the Armenian captivity. He spent 5 years in captivity and lived for 6 years after his release. On returning to this country, he openly practiced Christian religion, repenting that he had denied Christ.

But what should I say here? For although on returning they openly came back to the worship of Christ our God, they did not perform the canonical regulations in the correct manner, not only Ashot but all the Armenian princes who had been released. They rejected completely the corruption of apostasy but remained outside the canonical regulation, leading lives that were inconsistent with Christianity in terms of debauchery and drunkenness, of adulterous and disgusting behaviour, in terms of appalling and revolting [228] homosexual acts which surpassed the bestial acts associated with Jericho and the brazen conduct associated with Sodom, with man shamelessly lusting after man, incurring cascades of everlasting fire from heaven, worse than the deadly destruction of the Flood. Some of them strayed in pursuit of women, having intercourse with the daughters of Cain and were destroyed by water; others who engaged in disgraceful acts with men, were burned with a sulphurous fire, securing for themselves the certain prospect of the eternal fire.

But Ashot, when he reached the time for leaving this world, was plunged into the deepest remorse and regret; with copious tears he made confession, trusting for intercession in the mercy of Christ, repeating the last words of the tax collector and 


\begin{tabular}{l} 
the thief, looking in faith to the saving body and blood of the Son of God for the \\
forgiveness of sins, trusting in God's kindness. I do not despise or mock his remorse \\
and regret, for "whoever shall call on the name of the Lord shall live [Acts 2:21]". But \\
it is unclear if they were effective, for with difficulty are scars removed, according to \\
the holy injunctions. Yet, in the house of the Father of Christ, there are many \\
mansions. Perhaps they shall live and stay without torments, although they shall not \\
enjoy the wedding with the bridegroom. And so this man departed not without hope, \\
looking to God's kindness. \\
\hline Further reading: \\
\hline $\begin{array}{l}\text { Alison Vacca, "Conflict and Community in the Medieval Caucasus," Al- 'Ușūr al-Wusțā: The } \\
\text { Journal of Middle East Medievalists } 25 \text { (2017), 66-112 } \\
\text { Robert W. Thomson, "T'ovmay Arcruni's debt to Etišēe," Revue des Études Arméniennes } \\
18 \text { (1984): 227-35 }\end{array}$ \\
\hline
\end{tabular}

